\title{
Score Detection and Anemia Education Prospective Bridals Using Android Based Macca Botting Application
}

\author{
Kadek Agustina Puspa Ningrum ${ }^{1} \quad$ Andi Nilawati Usman $^{2}$ Syafruddin Syarif ${ }^{3}$ \\ 1.Department of Midwifery, Graduate School, Hasanuddin University, Indonesia \\ 2.Department of Obstetrics and Gynecology, Hasanuddin University, Indonesia \\ 3.Department of Electrical Engineering, Faculty of Engineering, Hasanuddin University, Indonesia
}

\begin{abstract}
Anemia is the highest cause of maternal death in Indonesia. Various methods were used to assist in preventing and overcoming anemia. The method used was Research and Development with the Borg and Gall development model which was simplified by the Research Center for Policy and Education Innovation Team of the National Education Research and Development Agency (Pultijaknov) and quantitative research methods with a quasi-experimental research design. The research was conducted in January-July 2020 at religious affairs office Biringkanaya Makassar. The subject of this research was the bride and groom at the Biringkanaya Religious Affairs Office in Makassar. Data analyzed used the Mann Whitney test. The results showed that the application of score detection and anemia education for the bride and groom was assessed by material experts with an average score of 3.30 (very good), the media expert's assessment was 3.25 (good) and the assessment of the prospective bride and groom in the small sample trial got a score of 3.63 (very good). The results of the large sample trial obtained $\mathrm{p}$ value $0.000<\mathrm{p}$ value 0.05 that the botting macca application has an effect on the detection of scores and anemia education of the prospective bride. The development of an Android-based Botting Macca application program can be developed and it was suitable for future used.
\end{abstract}

Keywords: android, anemia, score detection application, education.

DOI: $10.7176 /$ ALST/82-05

Publication date:October $31^{\text {st }} 2020$

\section{Introduction}

Anemia occupies the highest percentage of causes of maternal mortality in Indonesia, which is $28 \%$ (Kemenkes RI n.d). Anemia is a condition in which hemoglobin $(\mathrm{Hb})$ levels in the blood are less than normal $(12 \mathrm{~g} / \mathrm{dL})$ in women of childbearing age (Gómez-Ramírez et al. 2019). According to Panyang et al (2018), women of childbearing age are very susceptible to anemia, which is $55.3 \%$ at age (15-49 years) (Chowdhury and Chakraborty 2017). Anemia in women of childbearing age will affect cognitive development and behavior, energy metabolism, immunity, work capacity and conditions of pregnancy, childbirth and childbed (Mohebi et al. 2018). The main cause of anemia in women of childbearing age is a lack of intake of nutrients such as protein and vitamins (Bouri and Martin 2018), excessive coffee consumption, and less consumption of iron (Fe) tablets (Amanupunnyo, Shaluhiyah, and Margawati 2018). In addition, factors of poverty and low levels of education make WUS more vulnerable to anemia (Pasricha et al. 2015).

Women of childbearing age determine the condition of pregnant women and during pregnancy. The nutritional status and health of the mother before pregnancy, during pregnancy and during breastfeeding are critical periods for child growth and development. The first 1000 days of life are a sensitive and decisive period for the nation's future generations (Prieto-Patron et al. 2018). The proportion of women of childbearing age in Indonesia who received Blood Supplement Tablets in 2018 was $76.2 \%$. increased from 2013 to 2018, the increase was $11.8 \%$ (Ika Ratnawati, SKM 2019).

In fact, the Blood Supplement Tablet program has not been able to significantly reduce the number of anemia sufferers among women of childbearing age. The failure of this program is influenced by several factors, namely compliance in consuming Blood Supplement Tablets and improper way to consume Blood Supplement Tablets, both in terms of time and how to consume them (Dieny et al. 2019). The process of iron absorption is strongly influenced by the availability of vitamin $\mathrm{C}$ to help reduce ferri $\left(\mathrm{Fe}^{3+}\right)$ to ferro $\left(\mathrm{Fe}^{2+}\right)$ in the small intestine so that it is easily absorbed. (Sarah and Irianto 2018; Pradanti, M, and Sulistya 2015).

Audio visual media is considered more effective than leaflets (Putri, rezal, and Akifah 2017). Therefore, a more practical and efficient educational media is needed. The mobile smartphone application is more accessible to the public, especially women of childbearing age because it has several advantages, including speed and accuracy in making decisions and as a good data storage medium (Hidayah, Nurazizah, and Rahmawati 2019). In addition it has the ability to interpret and act on reminders and can detect differences over time (monitoring behavior change) (Litwin et al. 2018). In Indonesia the anemia application has been successfully made by Hamid et al (2020), this application has an early detection feature of anemia, but the application is still in the design stage and has not been tested in the community (Hamid et al. 2020). So that in this study, a new application called Botting Macca was developed. 
The Botting Macca application was designed to detect anemia scores by asking questions to the application user. The results of these questions were used as the basis for determining the user's health level. In addition, this application has added an automatic feature in the form of an alarm for drinking Blood Supplement Tablets and can monitor changes in user behavior. So, the application was expected to provide education and prevention of anemia for women of childbearing age who will become future brides.

\section{Method}

\subsection{Study design}

This study used Research and Development (R\&D) with the Borg and Gall development model and quasiexperimental pre-post test. This research method intends to develop or validate products applied in education (Short et al. 2018). The product will go through a validation test by a media expert, two material experts and a small $(n=10)$ and large $(n=40)$ sample trial (Amelia et al. 2020).

\subsection{Participants}

Respondents came from prospective brides who were taken by purposive sampling around January - July 2020 at religious affairs office Biringkanaya. The intervention group $(\mathrm{n}=20)$ was given Botting Macca application and the control group $(n=20)$ was given score detection and education by using print out media.

\subsection{Data collection}

Respondents in each group filled in the score detection section in the form of 12 questions related to signs of anemia symptoms including (5L (lethargy, tired, weak, tired, negligent), headache, dizzy eyes, easily drowsy, quickly tired, difficult to concentrate, pale on the face, pale on the lower eyelid, pale on the lips, pale on the skin, pale on the nails, pale on the palms) and monitored for research activities once a week, for 4 weeks.

\subsection{Data Analysis}

Processing and data analysis in this study were obtained from research instruments in the form of qualitative and quantitative data. Quantitative data were obtained from the recapitulation of the validation questionnaire of media experts, material experts and small sample tests as well as the results of pre-test and post-test trials. Meanwhile, qualitative data were obtained from suggestions / input from media and material experts after assessing the score detection application and anemia education for the bride and groom.

In this study, the product suitability score was decided in the range $2.51-3.25$ or 3.26-4.00 so, this aspect can be said to be valid and does not need to be revised of the score which can be seen in (Table 1).

Table 1. Value ranges and scales

\begin{tabular}{ll}
\hline Range & Value Scale \\
\hline Very good & $3.26-4.00$ \\
\hline Well & $2.51-3.25$ \\
\hline Enough & $1.76-2.50$ \\
\hline Not good & $1.00-1.75$ \\
\hline
\end{tabular}

Source: Nurhayati, 2019

\subsection{Research Ethics}

The study has received a recommendation of ethical approval from the Faculty of Public Health, Hasanuddin Makssar University with protocol number 7420092136.

\section{Result}

\subsection{Macca Botting Application Products Based on Android}

The product being developed was a scoring application and anemia education for prospective brides named botting macca which comes from the Bugis language and means smart bride, with this application the researchers hope that after the bride and groom use the application they can become smarter in acting especially in prevention and overcoming anemia.

\subsection{Media Expert Test Validation, Material Expert Test Validation, and Small Scale Sample Trials}

From the results of the application feasibility test answers, it can be assumed that the results of the assessment results from the media expert's assessment showed an average score of 3.25 in a good category (Table 2) in terms of media which includes application size, cover design and application content design is good, and Material experts showed an average score of 3.30 in a very good category (Table 3) in terms of material which includes aspects of content feasibility, presentation feasibility, presentation feasibility, language feasibility and contextual feasibility, and the respondent's assessment showed an average score of 3.63 in a very good category (Table 4) of the components of interest, material and language. Based on the results of the last description, it can be decided that 
the suitability score of the Macca Botting Application product with a minimum score of 3.39 was classified into the "Very Good" category.

Table 2. The results of the media expert's test of the botting macca application for score detection and anemia education of the bride and groom

\begin{tabular}{|c|c|c|}
\hline ASSESSMENT ASPECT & $\begin{array}{c}\text { MEDIA } \\
\text { EXPERTS }\end{array}$ & $\begin{array}{c}\text { AVERAGE } \\
\text { RATING }\end{array}$ \\
\hline Application Size & 3.5 & 3.5 \\
\hline Suitability of application size with ISO standards & 3 & \\
\hline Suitability of size with the content of the application & 4 & \\
\hline Cover Design & 3.25 & 3.25 \\
\hline Appearance of layout elements & 3 & \\
\hline Color layout elements & 4 & \\
\hline The letters used are attractive and easy to read & 3 & \\
\hline 6. Application cover illustration & 3 & \\
\hline Application Content Design & 3 & 3 \\
\hline 7. Consistency of appearance layout & 3 & \\
\hline 8. $\quad$ Printable and space layout elements & 3 & \\
\hline 9. Title layout elements and illustrations & 3 & \\
\hline 10. Embedding layout & 3 & \\
\hline 11. Typography of simple application contents & 3 & \\
\hline 12. Typography of the app content makes it easy to understand & 3 & \\
\hline 13. Content illustration & 3 & \\
\hline Average & 3.25 & 3.25 (Good) \\
\hline
\end{tabular}

Table 3.The results of the material expert's test on the botting macca application for score detection and anemia education in the bride-to-be

\begin{tabular}{lccc}
\hline \multicolumn{1}{c}{ Component } & EXPERT I & EXPERT II & Average rating \\
\hline Content Feasibility Aspects & $\mathbf{3 , 6}$ & $\mathbf{2 . 6 5}$ & $\mathbf{3 . 1 2}$ \\
\hline 5. Material suitability & 4 & 3.5 & \\
\hline 6. Material accuracy & 3,4 & 2,6 & \\
\hline 7. Material finesse & 3 & 2.5 & $\mathbf{3 . 2 7}$ \\
\hline 8. Encourage curiosity & 4 & 2 & \\
\hline Presentation Feasibility Aspects & $\mathbf{3 . 9 5}$ & $\mathbf{2 , 6}$ & \\
\hline 5. Presentation technique & 4 & 3 & $\mathbf{3 . 5}$ \\
\hline 6. Serving support & 3.8 & 2,4 & \\
\hline 7. Presentation of learning & 4 & 2 & \\
\hline 8. Coherence and sequence of thought & 4 & 3 & \\
\hline Aspects of Language Eligibility & $\mathbf{3 . 8}$ & 4 & \\
\hline 6. Straightforward & 4 & 3 & $\mathbf{3 . 3 2}$ \\
\hline 7. Communicative & 4 & 3 & \\
\hline 8. Diagnosis and interactive & 4 & 3 & \\
\hline 9. Conformity with development & 3 & 3 & $\mathbf{3 . 3 0}$ \\
\hline 10. Compliance with language rules & 4 & 3 & (Very good) \\
\hline Aspects of Contextual Eligibility & $\mathbf{3 . 6 5}$ & 3 & \\
\hline 3. Contextual nature & 3.5 & $\mathbf{2 . 8 6}$ & \\
\hline 4. Contextual component & 3.8 & $\mathbf{3 . 7 5}$ & \\
\hline
\end{tabular}

Table 4. The results of the respondent's trial of the botting macca application for score detection and anemia education in the bride-to-be

\begin{tabular}{cc}
\hline Component & Average value \\
\hline Interest & 3.63 \\
\hline Theory & 3.67 \\
\hline Language & 3,6 \\
\hline \multirow{2}{*}{ Average } & $\mathbf{3 . 6 3}$ \\
& (Very good) \\
\hline
\end{tabular}




\subsection{Large-Scale Sample Trials}

In Table 5, it was found that the two groups of respondents who were prospective brides for the normal, high-risk and anemia categories most were $20-30$ years old by $90 \%$ (18 respondents) with 10 respondents $(50 \%)$ as private employment status.

Table 5. Description of Characteristics

\begin{tabular}{|c|c|c|c|c|c|c|c|c|}
\hline \multirow{3}{*}{$\begin{array}{l}\text { Variable } \\
\text { Age }\end{array}$} & \multicolumn{8}{|c|}{ Macca Botting Application } \\
\hline & \multicolumn{2}{|c|}{ Normal } & \multicolumn{2}{|c|}{ Highrisk } & \multicolumn{2}{|c|}{ Anemia } & \multicolumn{2}{|c|}{ Total } \\
\hline & $\mathbf{n}$ & $\%$ & $\mathbf{n}$ & $\%$ & $\mathbf{n}$ & $\%$ & $\mathbf{n}$ & $\%$ \\
\hline$\leq 19$ years & 1 & $5 \%$ & - & - & 1 & $5 \%$ & 2 & $10 \%$ \\
\hline 20-30 years & 6 & $30 \%$ & 6 & $30 \%$ & 6 & $30 \%$ & 18 & $90 \%$ \\
\hline$\geq 30$ years & - & - & - & - & - & - & - & - \\
\hline \multirow[t]{2}{*}{ Total } & & & & & & & 20 & $100 \%$ \\
\hline & \multicolumn{4}{|c|}{ Media Print Out } & & & & \\
\hline$\leq 19$ years & - & - & - & - & - & - & - & - \\
\hline 20-30 years & 8 & $40 \%$ & 7 & $35 \%$ & 5 & $25 \%$ & 20 & $100 \%$ \\
\hline$\geq 30$ years & - & - & - & - & - & - & - & - \\
\hline \multirow[t]{2}{*}{ Total } & & & & & & & 20 & $100 \%$ \\
\hline & \multicolumn{6}{|c|}{ Macca Botting Application } & & \\
\hline \multirow{2}{*}{ Profession } & \multicolumn{2}{|c|}{ Normal } & \multicolumn{2}{|c|}{ Highrisk } & \multicolumn{2}{|c|}{ Anemia } & \multicolumn{2}{|c|}{ Total } \\
\hline & $\mathbf{n}$ & $\%$ & $\mathbf{n}$ & $\%$ & $\mathbf{n}$ & $\%$ & $\mathbf{n}$ & $\%$ \\
\hline IRT & 1 & $5 \%$ & - & - & - & - & 1 & $5 \%$ \\
\hline entrepreneur & - & - & - & - & - & - & - & - \\
\hline Private & 2 & $10 \%$ & 4 & $20 \%$ & 4 & $20 \%$ & 10 & $50 \%$ \\
\hline PNS / Honorary & 1 & $5 \%$ & - & - & 2 & $10 \%$ & 3 & $15 \%$ \\
\hline Work / other & 3 & $15 \%$ & 2 & $10 \%$ & 1 & $5 \%$ & 6 & $30 \%$ \\
\hline \multirow[t]{2}{*}{ Total } & & & & & & & 20 & $100 \%$ \\
\hline & \multicolumn{4}{|c|}{ Media Print Out } & & & & \\
\hline IRT & - & - & - & - & - & - & - & - \\
\hline entrepreneur & - & - & - & - & - & - & - & - \\
\hline Private & 6 & $30 \%$ & 6 & $30 \%$ & 3 & $15 \%$ & 15 & $75 \%$ \\
\hline PNS / Honorary & 2 & $10 \%$ & 1 & $5 \%$ & 2 & $10 \%$ & 5 & $25 \%$ \\
\hline Work / other & - & - & - & - & - & - & - & - \\
\hline Total & & & & & & & 20 & $100 \%$ \\
\hline
\end{tabular}

Based on table 6 , it was found that the difference in the detection score of anemia scores in the prospective bride showed that the pre-test and post-test when using the botting macca application, all items decreased on average, while when using print out media, all items increased on average.

Table 6. Average Test Results Pre Test and Post Test Detection of Anemia Score

\begin{tabular}{lllll}
\hline \multirow{2}{*}{ Item } & \multicolumn{2}{l}{ Macca Botting Application } & \multicolumn{2}{l}{ Media Print Out } \\
\cline { 2 - 5 } 5L (Sluggish, Tired, Weak, Tired, Inattentive) & \multicolumn{1}{l}{ Pre Test } & Post Test & Pre Test & Post Test \\
\hline Headache / dizziness & 14 & 1 & 9 & 11 \\
\hline Firey eyes & 20 & 3 & 17 & 20 \\
\hline Drowsiness & 7 & 0 & 3 & 4 \\
\hline Tired quickly & 19 & 19 & 20 & 20 \\
\hline Difficult to Concentrate & 19 & 18 & 20 & 20 \\
\hline Face Pale & 12 & 13 & 20 & 20 \\
\hline Pale of the Lower Eyelids & 6 & 1 & 11 & 17 \\
\hline Pale on the lips & 14 & 3 & 10 & 14 \\
\hline Pale to the skin & 14 & 4 & 10 & 13 \\
\hline Pale on the Nails & 3 & 0 & 0 & 1 \\
\hline Pale on the palms & 11 & 2 & 5 & 10 \\
\hline \multicolumn{1}{l}{ Bas (1) } & 4 & 0 & 0 & 0
\end{tabular}

Based on the results of table 7, it was found that the difference in status changed in the prospective bride showed the pre-test and post-test when using the botting macca application, all items on average from anemia and highrik become normal, while when using print out media, all items on average experience changed from normal to high risk and from hypertension to anemia. 
Table 7. Results of Pre Test and Post Test Monitoring of Anemia Education

\begin{tabular}{|c|c|c|c|c|}
\hline \multirow{3}{*}{ Item } & \multicolumn{2}{|c|}{ Macca Botting Application } & \multicolumn{2}{|c|}{ Media Print Out } \\
\hline & Pre Test & Post Test & Pre Test & Post Test \\
\hline & Score $(\%)$ & Score $(\%)$ & Score $(\%)$ & Score $(\%)$ \\
\hline Anemia & $6(30)$ & $0(0)$ & $1(5)$ & $5(25)$ \\
\hline Highrix & $8(40)$ & $2(10)$ & $11(55)$ & $10(50)$ \\
\hline Normal & $6(30)$ & $18(90)$ & $8(40)$ & $5(25)$ \\
\hline
\end{tabular}

In table 8 , the results of the Man-Whitney statistical test obtained $p$ value $0.001<p$ value 0.05 , so Ho is rejected, Ha is accepted, which means there was a difference in the effect of using the botting macca application for score detection and anemia education with print out media on the prospective bride. The result of the mean rank of the experimental group that was given botting macca application was 27.25, while the control group who was given print out media was 13.75 .

Table 8. Mann-Whitney test

\begin{tabular}{llll}
\hline Media & N & Mean Rank & p-Value \\
\hline Macca Botting Application & 20 & 27.25 & 0,000 \\
\hline Print Out & 20 & 13.75 & \\
\hline
\end{tabular}

\section{Discussion}

The product being developed was a scoring application and anemia education for prospective brides named botting macca which comes from the Bugis language and means smart bride, with this application the researchers hope that after the bride and groom use the application they can become smarter in acting, especially in prevention and overcoming anemia. The following are some of the features contained in the macca botting application:

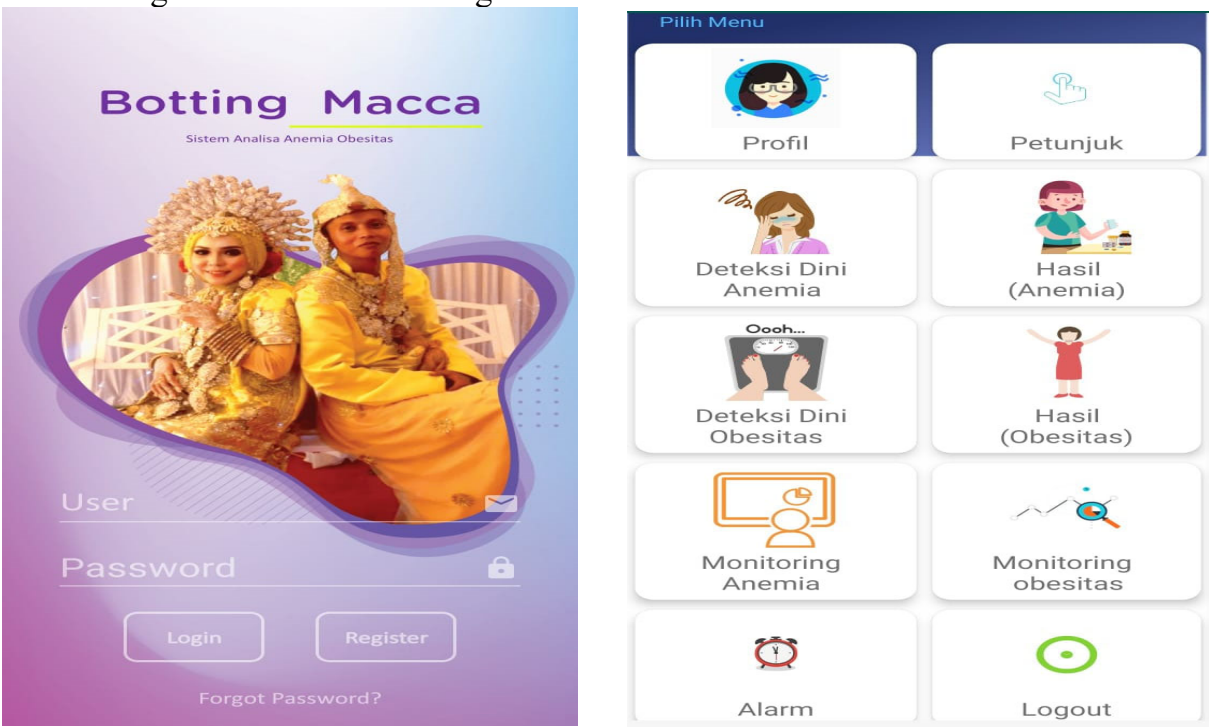

Figure 1. Menu entry and display of application features

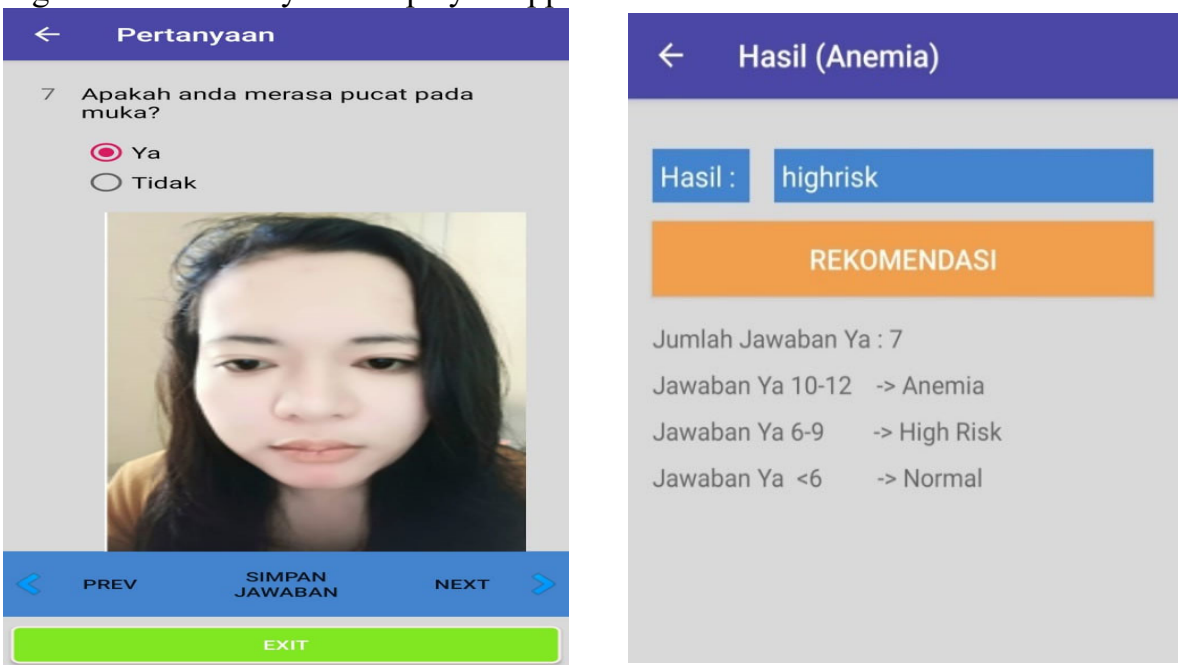

Figure 2. One question detection score and results of anemia status 


\section{$\leftarrow$ Detail}

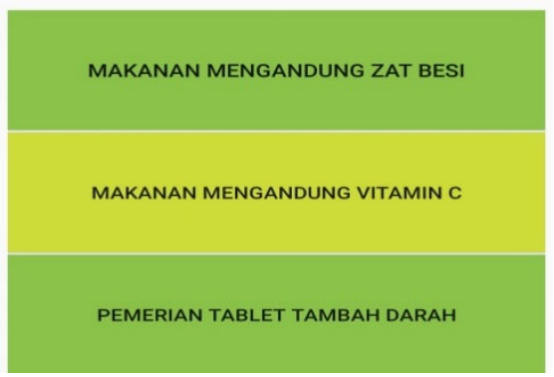

\begin{tabular}{|c|c|c|}
\hline Jenis makanan & Porsi permenu & Konversi \\
\hline \multicolumn{3}{|l|}{ Sumber nabati } \\
\hline Kacang kedelai & $50 \mathrm{gram}$ & $5 \mathrm{sdm}$ \\
\hline Kacang tanah & $20 \mathrm{gram}$ & $2 \mathrm{sdm}$ \\
\hline Petai segar & $20 \mathrm{gram}$ & $\begin{array}{l}1 \text { papan biji } \\
\text { besar }\end{array}$ \\
\hline Tahu & 100 gram & 2 potong sedang \\
\hline Sari kedelai & $185 \mathrm{gram}$ & 2,5 gelas \\
\hline Tempe & $50 \mathrm{gram}$ & 2 potong sedang \\
\hline
\end{tabular}

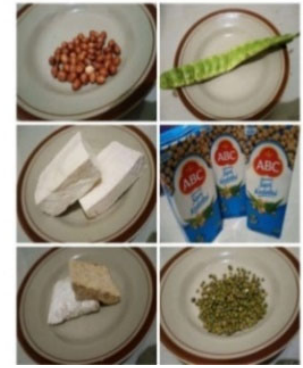

\section{$\leftarrow \quad$ Detail Porsi}

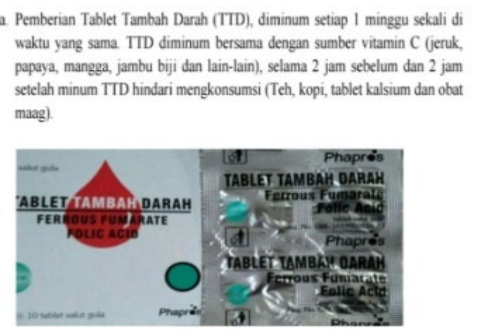

Figure 3. Anemia Education

How to fill in the detection of anemia scores is by downloading the botting macca application found on the Android plystore, then you can install the application and open the application in which there are several features as follows: user profile, instructions for using the application, detection of anemia scores, results and education of anemia, monitoring anemia, alarm reminders to drink blood plus tablet and logout menu. Furthermore, to run the application, users can open and fill in the user profile feature, open and understand the application usage instructions feature, select and open the anemia score detection feature in the botting macca application, Then the user selects the anemia score detection feature, which contains 12 questions for the detection of anemia scores and can fill in the 12 questions by choosing a yes or no answer according to what was experienced by the prospective bride. The more yes statements chosen, the greater the chance of anemia happened. Through the results of the calculation of the answers, the prospective bride can assess whether she was included in the category of risk of anemia or not. If the bride-to-be knew that she was at risk of anemia, it was hoped that she can be more vigilant 
and apply the education contained in the anemia education feature in the botting macca application (MHN Sari and Anggraini 2020), early detection can prevent anemia in an effort to reduce AKI (Solehati et al. 2018), early detection efforts can be done in adolescents (DP Sari et al. 2020; Abdimas and Tasikmalaya 2019; Umriaty and Arti 2019; Putrianti and Krismiyati 2019) and early detection in pregnant women (Fitri and Machampang 2018; Sukmawati, Mamuroh, and Nurhakim 2019; Saryono nd)

From the results of the validation test by the media expert and material expert as well as the small sample trial, it can be assumed that the results of the material expert's assessment showed an average score of 3.30 (very good), while the media expert showed a score of 3.25 (good). The criteria for the assessment results in accordance with the results of the study were very feasible and can be used without revision (Candradewi, Saputri, and Adnan 2020).

The advantages possessed by this application are that the application display given an attractive animation on each feature so, it does not bore users. In addition, the content of the material contained in the application uses communicative language and easy to understand and is equipped with pictures, in the botting macca application it is also equipped with an alram feature for drinking blood supplement tablets.

Based on the results of the research, in addition to the content of the material contained in the application using communicative language and easy to understand by the bride-to-be respondents which was proven by the assessment obtained by the researcher, the results showed that the average small-scale test recapitulation results on users of the botting macca application for score detection and anemia education for the bride-to-be with the interest components, material and language was at 3.63 in the very good category. So, the Macca botting application can be said to be suitable for use and does not need to be revised. After the botting macca application product for score detection and anemia education in the bride-to-be was categorized as feasible according to product testing by media experts, material and small-scale user testing, furthermore this botting macca application can be developed and given directly to bride-to-be respondents to measure its effect on score detection and anemia education for the bride-to-be.

In this study, the results of the description of the characteristics of the two groups of respondents to the prospective bride for the normal, high-risk and anemia categories most were 20-30 years old by $90 \%$ (18 respondents) in the group given the botting macca application and 100\% (20 respondents) in the control group who was given print out media. In the two groups of respondents, the prospective bride and groom have the most work status as private as many as 10 respondents $(50 \%)$ in the group given the botting macca application and as many as 15 respondents (75\%) in the control group, these all from the normal, high-risk and high-risk categories, anemia.

These results were consistent with research conducted by Zahidatul \& Trias (2017) that women aged $<20$ years have a risk of experiencing anemia 2,250 times compared to those aged 20-35 years, and those aged $>35$ years have a risk of experiencing anemia 5.885 times greater than those aged 20-35 years old. Women who do not work have a risk of experiencing Anemia 1,990 greater than pregnant women who work (Zahidatul Rizkah and Trias Mahmudiono 2017).

This study found that the results of using the botting macca application were feasible to detect scores of anemia in prospective brides. This was in line with a number of studies conducted using applications as the main medium for early detection of women (MHN Sari and Anggraini 2020; Solehati et al. 2018; DP Sari et al. 2020; Abdimas and Tasikmalaya 2019; Umriaty and Arti 2019; Putrianti and Krismiyati 2019; Fitri and Machampang 2018; (Sukmawati, Mamuroh, and Nurhakim 2019)

This botting macca application used a score detection feature which contained 12 questions related to signs of anemia, including: 5L (tired, lethargic, weak, tired, inattentive), headache, dizzy eyes, easily drowsy, tired quickly, difficult to concentrate, pale on the face, pale on the lower eyelids, pale on the lips, pale on the skin, pale on the nails, pale on the palms of the hands. Respondents filled in the score detection item section on the botting macca application once a week. Based on the results of research conducted in the experimental group by given the botting macca application, of the 20 respondents the most answered yes to symptoms of easy drowsiness and tiredness, namely 19 respondents. Meanwhile, the control group was given print out media from the 20 respondents who answered yes to the symptoms of easy drowsiness, fatigue and difficulty concentrating, as many as 20 respondents. This was in line with research conducted by Julia in 2018 that anemia can be detected with several symptoms including 5L, dizziness, dizziness, drowsiness, fatigue, difficulty concentrating, pale conjunctiva, pale lips and face (Fitriany and Saputri 2018).

Based on the results of research conducted in the experimental group by given the botting macca application, of the 20 respondents the most were in the hygienic category, namely 8 respondents (40\%) and decreased significantly for 4 weeks to 2 respondents $(10 \%)$. Whereas the control group was given print out media from 20 respondents, the most were in the high-risk category, namely 11 respondents (55\%) and after 4 weeks it decreased to 10 respondents $(50 \%)$. This was in line with the study by Emma Tonkin (2017) who tested a smartphone application to improve nutrition in community settings, it was found that there was a change in behavior in food selection that affected a person's health condition (Tonkin, Brimblecombe, and Wycherley 2017). 
This study found that the application of score detection and anemia education in the bride and groom-to-be was feasible and has the potential to be developed in increasing the behavior changed of the bride and groom. This was in line with the benefits and uses of mobile-based applications as an information medium in pregnancy, that most women use internet access to retrieve health information (Selvia and Ernawati 2019).

The results of the Mann-Whitney test with a p-value of $0.001<0.05$, in line with research which showed that there were significant differences in nutritional knowledge and levels of nutritional adequacy related to anemia prevention after nutrition education was given (Sefaya 2017).

Using applications compared to print outs made it easier for respondents to add education. The implication of this research was that it made it easier to study anemia material in the bride-to-be and it was proven to be able to increase the behavior changed of the bride-to-be so, this application was considered feasible and can be used as an educational medium. Various forms of application according to the times that are web-based and smartphone are proven to increase knowledge (Noverina, Dewanti, and Sitoayu 2020; Publication 2017; Fadhilah, Hartini, and Alit Gunawan 2017) Besides being able to increase knowledge, it can also have an influence on maternal attitudes related to anemia (Febrianta, Gunawan, and Sitasari 2019; Ferwanda and Muniroh 2017), and can increase the effectiveness of health promotion (Mahampang and Sari 2020; Rotua 2018; Putu Fani Yustisa, Aryana, and Suyasa 2012).

The availability of a score detection application and anemia education for the bride and groom was expected to have a positive impact in increasing public awareness, especially the bride and groom to do something that can help themselves related to anemia. If a person already has knowledge, with this knowledge he will have the ability to use the material he has learned in real situations and circumstances (Iron, Knowledge, and 2019).

\section{Conclusion}

Based on the development model of Borg \& Gall, a product called an android-based botting macca application produced for scoring detection and education of anemia among aspirants. Based on the assessment of the expert test covering the components of application size, cover design, application content design, aspects of feasibility, presentation, language and context, the application of score detection and anemia education in the bride and groom was suitable for use without revision. Based on the pre and post test assessments for sample trials, the detection score and anemia education of the bride and groom were feasible to use without revision and were feasible to be developed.

Based on further development research, it was hoped that the components of score detection and education related to the health of the bride and groom can be developed so, they can add features in the botting macca application, add interesting anemia educational videos and can add HB diagnostic tests to confirm the results of detection of anemia scores, and can add sympton or symptom and sign or sign / indication in section 12 question in score detection feature.

\section{Reference}

Abdimas, Jurnal, and Kesehatan Tasikmalaya. 2019. "Jurnal Abdimas Kesehatan Tasikmalaya Volume 1 Nomor 1 April 2019." 1(April): 2018-20.

Amanupunnyo, Notesya Astri, Zahroh Shaluhiyah, and Ani Margawati. 2018. "Analisis Faktor Penyebab Anemia Pada Ibu Hamil Di Puskesmas Kairatu Seram Barat." Jurnal Aisyah : Jurnal Ilmu Kesehatan 3(2): $173-81$.

Amelia, Kiki et al. 2020. "A Digital Partograph Model As Learning Media For The Normal Childbirth Care." 24(04): 5624-31.

Besi, Suplementasi, Terhadap Pengetahuan, and Sikap Dan. 2019. "EFEKTIVITAS INTERVENSI PENDIDIKAN GIZI PADA PROGRAM Effectiveness of Nutritional Education Intervention in Iron Suplementation Programs On." 3(2): 47-51.

Bouri, Sonia, and John Martin. 2018. "Investigation of Iron Defi Ciency Anaemia." Clinical Medicine, Journal of the Royal College of Physicians of London 18(3): 242-44.

Candradewi, Susan Fitria, Ginanjar Zukhruf Saputri, and Adnan Adnan. 2020. "Validasi Kuesioner Pengetahuan Anemia Dan Suplemen Zat Besi Pada Ibu Hamil.” Jurnal Pharmascience 7(1): 18.

Chowdhury, Subhankar, and Partha pratim Chakraborty. 2017. "Universal Health Coverage - There Is More to It than Meets the Eye." Journal of Family Medicine and Primary Care 6(2): 169-70. http://www.jfmpc.com/article.asp?issn=22494863; year $=2017$; volume $=6$; issue $=1$; spage $=169$; epage $=170$; aulast $=$ Faizi .

Dieny, Fillah Fithra et al. 2019. "Iron Deficiency in Preconception Women with Obesity Fillah." Media Gizi Mikro Indonesia 10(2): 101-10.

Fadhilah, Dina, Th Ninuk Sri Hartini, and I Made Alit Gunawan. 2017. "Efektifitas Penyuluhan Tentang Sayuran Menggunakan Media 'Kartu Sayuran' Terhadap Peningkatan Pengetahuan Siswa Sekolah Dasar.” Jurnal Nutrisia 19(2): 100.

Febrianta, Ridwan, I Made Alit Gunawan, and Almira Sitasari. 2019. "Pengaruh Media Video Terhadap 
Pengetahuan Dan Sikap Ibu Hamil Tentang Anemia Di Wilayah Kerja Puskesmas Nanggulan Kabupaten Kulon Progo." Jurnal Teknologi Kesehatan (Journal of Health Technology). 15(2): 81-90. file://D:/SKRIPSI/jurnal di proposal/412-Article Text-998-1-10-20191125.pdf.

Ferwanda, Anja Farahyani, and Lailatul Muniroh. 2017. "Efektivitas Buku Edukatif Berbasis Games Terhadap Perubahan Pengetahuan Serta Sikap Tentang Sayur Dan Buah ( Studi Di SDN Suko 1 Kabupaten Sidoarjo ) The Effectiveness of Games-Based Educative Book on The Change Of Knowledge And Attitude About Vegetables ." : 389-97.

Fitri, Annisa, and Machmudah. 2018. "Studi Deskriptif Kemampuan Deteksi Dini Anemia Pada Ibu Hamil Di Kota Semarang Descriptive Study of Early Anemia Detection Ability in Pregnant Women In Semarang City." Proceeding Unissula Nursing Conference Tema: "Nurse Roles in Providing Spiritual Care in Hospital, Academic and Community": 180-87.

Fitriany, Julia, and Amelia Intan Saputri. 2018. “Anemia Defisiensi Besi. Jurnal." Kesehatan Masyarakat 4(1202005126): 1-30.

Gómez-Ramírez, Susana et al. 2019. "Management of Perioperative Iron Deficiency Anemia." Acta Haematologica 142(1): 21-29.

Hamid, M Abdul, Budhi Irawan, S Si, and Muhammad Faris R. 2020. "Perancangan Aplikasi Deteksi Dini Penyakit Anemia Menggunakan Sistem Pakar Dengan Metode Forward Chaining Berbasis Android Design Application Early Detection of Anemia Disease Using Expert System With Method Forward Chaining Based on Android." 7(1): 1586-92.

Hidayah, Luluk, Yayuk Nurazizah, and Ita Rahmawati. 2019. "Pengembangan Media Edukasi Kesehatan Berbasis E-Book." Seminar Nasional Teknologi dan Informatika: 57-62.

Ika Ratnawati, SKM, MKKK. 2019. “Generated From.” Kemenkes: 2015. http://www.kesmas.kemkes.go.id/portal/konten/ rilis-berita/021517-di-rakesnas-2019_-dirjen-kesmaspaparkan-strategi-penurunan-aki-dan-neonatal.

Kemenkes RI, 2015. LAPORAN AKUNTABILITAS KINERJA KEMENTERIAN KESEHATAN TAHUN2014.

Litwin, Lindsay Elizabeth et al. 2018. "Use of an Electronic Partograph: Feasibility and Acceptability Study in Zanzibar, Tanzania." BMC Pregnancy and Childbirth 18(1): 1-11.

Mahmudah, Umi, and Siska Puspita Sari. 2020. "Pengaruh Penggunaan Media Cakram Gizi Terhadap Pengetahuan Remaja Mengenai Konsumsi Buah Dan Sayur.” Ilmu Gizi Indonesia 3(2): 155.

Mohebi, Siamak, Mahmoud Parham, Gholamreza Sharifirad, and Zabihollah Gharlipour. 2018. "Social Support and Self - Care Behavior Study." (June): 1-6.

Noverina, Dhita, Lintang Purwara Dewanti, and Laras Sitoayu. 2020. "Pengaruh Explanation Video Terhadap Pengetahuan Dan Kepatuhan Konsumsi Tablet Tambah Darah Di SMPN 65 Jakarta Utara.” Darussalam Nutrition Journal 4(1): 35.

Pasricha, Sant-rayn et al. 2015. "Review Article Control of Iron de Fi Ciency Anemia in Low- and Middle-Income Countries." 121(14): 1-3.

Pradanti, Canthia Mahameru., Wulandari. M, and Hapsari K. Sulistya. 2015. "Hubungan Asupan Zat Besi (Fe) Dan Vitamin C Dengan Kadar Hemoglobin Pada Siswi Kelas VIII SMP Negeri 3 Brebes." Jurnal.Unimus.Ac.Id 4(1): 24-29. https://jurnal.unimus.ac.id/index.php/jgizi/article/view/1414.

Prieto-Patron, Alberto, Klazine Van der Horst, Zsuzsa V. Hutton, and Patrick Detzel. 2018. "Association between Anaemia in Children 6 to 23 Months Old and Child, Mother, Household and Feeding Indicators." Nutrients 10(9).

Publikasi, Naskah. 2017. "EFEKTIFITAS MEDIA VIDEO DAN LEAFLET TERHADAP PENGETAHUAN TENTANG ANEMIA SISWI SMAN 2 NGAGLIK."

Putri, A., F. rezal, and A. Akifah. 2017. "Efektifitas Media Audio Visual Dan Leaflet Terhadap Peningkatan Pengetahuan, Sikap Dan Tindakan Tentang Pencegahan Penyakit Gastritis Pada Santriwati Di Pondok Pesantren Hidayatullah Putri Dan Ummusshabri Kota Kendari Tahun 2017." Jurnal Ilmiah Mahasiswa Kesehatan Masyarakat Unsyiah 2(6): 184073.

Putrianti, Berliana, and Murti Krismiyati. 2019. "Deteksi Dini Penyakit Anemia Pada Remaja Di Posyandu Remaja Dusun Biru Sleman Yogyakarta.” Jurnal Pengabdian Masyarakat Karya Husada 1(2): 14-21.

Putu Fani Yustisa, I Ketut Aryana, and I Nyoman Gede Suyasa. 2012. "Efektivitas Penggunaan Media Cetak Dan Media Siswa Sd.” Jurnal Kesehatan Lingkungan 2(3): 29-39.

Rotua, Manuntun. 2018. "Efktivitas Edukasi Gizi Terhadap Perbaikan Asupan Zat Besi, Protein, Dan Kadar Hemoglobin Pada Siswa/i SMA Negeri 14 Palembang.” Jurnal Kesehatan Palembang 12(2): 161-68.

Sarah, Sophia, and Irianto Irianto. 2018. "Pengaruh Tingkat Kepatuhan Minum Tablet Fe Terhadap Kejadian Anemia Pada Ibu Hamil Trimester III Di Puskesmas Pejeruk Tahun 2017." YARSI Medical Journal 26(2): 075.

Sari, D P, S Ridmadhanti, R Erda, and ... 2020. "Deteksi Dini Anemia Pada Remaja Di Pulau Nguan Kecamatan Galang Kota Batam Tahun 2020.” Jurnal Pelayanan ... 4(1): 1-9. 
http://ejournal.urindo.ac.id/index.php/PAMAS/article/view/767.

Sari, Marlynda Happy Nurmalita, and Dina Dewi Anggraini. 2020. "Penyuluhan Dan Deteksi Dini Anemia Menuju Generasi Berkualitas Pada Mahasiswa Kebidanan.” Jurnalempathy.Com 1(1): 72-84.

Saryono. "Penggunaan Hemoglobinometer Digital Untuk Deteksi Dini Dan Pencegahan Anemia Pada Ibu Hamil Di Desa Susukan, Kecamatan Sumbang, Kabupaten Banyumas."

Sefaya, Khoirunisa Triavi. 2017. "Pengaruh Pendidikan Gizi Terhadap Pengetahuan Gizi Dan Tingkat Kecukupn Gizi Terkait Pencegahan Anemia Remaja.” 5.

Selvia, Anisya, and Dwi Ernawati. 2019. "Manfaat Dan Kegunaan Aplikasi Berbasis Seluler Sebagai Media Informasi Dalam Kehamilan : Review Artikel.” Jurnal Bidan Komunitas 2(2): 76.

Short, Camille E., Amy Finlay, Ilea Sanders, and Carol Maher. 2018. "Development and Pilot Evaluation of a Clinic-Based MHealth App Referral Service to Support Adult Cancer Survivors Increase Their Participation in Physical Activity Using Publicly Available Mobile Apps.” BMC Health Services Research 18(1): 1-11.

Solehati, Tetti, Citra Windani Mambang Sari, Mamat Lukman, and Cecep Eli Kosasih. 2018. "Pengaruh Pendidikan Kesehatan Terhadap Pengetahuan Deteksi Dini Dan Pencegahan Anemia Dalam Upaya Menurunkan Aki Pada Kader Posyandu." Jurnal Keperawatan Komprehensif 4(1): 7.

Sukmawati, Lilis Mamuroh, and Furkon Nurhakim. 2019. "Pengaruh Edukasi Pencegahan Dan Penanganan Anemia Terhadap Pengetahuan Dan Sikap Ibu Hamil.” Jurnal Keperawatan BSI VII(1): 42-47.

Tonkin, Emma, Julie Brimblecombe, and Thomas Philip Wycherley. 2017. "Characteristics of Smartphone Applications for Nutrition Improvement in Community Settings: A Scoping Review." Advances in Nutrition 8(2): 308-22.

Umriaty, and Tias Dwi Arti. 2019. "Upaya Penurunan Anemia Pada Remaja Putri Dengan Deteksi Dini Dan Suplementasi Zat Besi Pada Siswi Sekolah Menengah Kejuruan (SMK).” Jurnal Pengabdian Dharma Bakti 2(2): 51-57. http://dharmabakti.respati.ac.id/index.php/dharmabakti/article/view/90.

Zahidatul Rizkah, and Trias Mahmudiono. 2017. "Hubungan Antara Umur, Gravida, Dan Status Bekerja Terhadap Resiko Kurang Energi Kronis (KEK) Dan Anemia Pada Ibu Hamil.” Amerta Nutrition 1(2): 72-79. 